\title{
The Effect of Artists' Communication Style on the Existence of Traditional Art: A Study on the Tembang Sunda Cianjuran Community in Indonesia
}

\section{J. Julia*}

\begin{abstract}
This paper aims at analyzing the communication styles of artists in Indonesia, which has an impact on the preservation of a traditional art genre that is Tembang Sunda Cianjuran (Cianjur Sundanese Traditional Song). The study was conducted with a qualitative method using an interdisciplinary approach. Results show that the communication styles formed by artists in the Tembang Sunda Cianjuran communities in West Java, Indonesia, is dominated by the relator and the socializer styles. These communication styles results in Tembang Sunda Cianjuran not losing enthusiasts, so that its existence is maintained from generation to generation.
\end{abstract}

Keywords: artists' communication style, tembang sunda cianjuran, sundanese traditional songs, traditional art existence, traditional art preservation.

\section{INTRODUCTION}

The problem of communication has always been the center of attention of philosophers, artists, theologians, etc. (Gladyshev, Kouznetsova, \& Penner, 2016). This phenomenon leads to diverse directions of communication studies. Some references indicate communication studies in the areas of the world and modern people (Heidegger, 1971; Huntington, 1992; Toffler \& Alvin, 1981; Visockis, 2015). One perspective affirms that the old ways of thinking ... dogmas, and ideologies, no matter how cherished or how useful in the past, no longer fit the facts. The world that is fast emerging ... new values and technologies, new geopolitical relationships, new lifestyles, and modes of communication (Visockis, 2015). On the other hand, there are communication studies in the fields of socio-culture (Bhatia, 1995, 2010; Blyler \& Thralls, 1993; Hargie, 1997; Mayhew, 1997; Pan, Scollon, \& Scollon, 2002; Tatu \& Arhire, 2012) and art (Santosa, 2012). However, recent communication studies are more directed to communication in public life in the technology era (Muljono, Setiyawati, \& Haryanto, 2017).

In theoretical context, various studies have been done as an attempt to construct a theory of communication (Fajar, 2011; Hardjana, 2004; N. Kurnia, 2005; Mahmudah, 2011; Purwandoko \& Prasetyo, 1993; Rahardjo, 2011; Rejeki \& Ninik, 2010). According to (Surahman, 2005, p. 126), communication theory is the science that leads to practical and complex matters. Some other reference sources agree that the theory of communication is a term that covers the general principles and statements designed to explain the causes and key relationships between aspects that exist in communicative behavior (Griffin, 1991; Stacks, Hill, \& Hickson, 1991; Sunarto, 2013, p. 54). The experts of communication, in addition to having a common view, also have different views on the dimensions of communication theory (Craig, 2007; Fisher, 1978; Fiske, 2003; Littlejohn, 1999; Miller, 2004). One widely used perspective states that tradition in the communication theory is ways of thinking and speaking that has been established and sowed continuously as a special discourse. According to Craig (2007) and Sunarto (2013), this discourse is the result of study and explanation (even

*Universitas Pendidikan Indonesia, email: juli@upi.edu 
standardization) by scientists and others involved in the discursive activity in a period of time related to communication problems experienced in daily life.

Considering aforementioned views, the perspective used in this study is the one that leads to culture communication as a way of thinking, speaking, and behaving so as to reflect the communication style of a person in a particular culture. Communication style is a combination of various components, such as voice patterns, eye movements, and facial expressions (Franksiska, 2006). In this study, the examined communication style is the style of Sundanese artists that has led to the preservation of Tembang Sunda Cianjuran (henceforth TSC) in Indonesia. Meanwhile, artists are people who are quite unique in their communication. Research results mentioned that artists have different communication styles, such as the style of comparison, contradiction, engagement, and repetition (Mukhlishin, Maryaeni, \& Pratiwi, 2016).

To examine the artists' communication styles, this study uses a concept of communication style formulated by Jensen (2001, 2004), who are inspired by Jung (1974) and Cathcart and Allesandra (1984). Jensen's concept is translated into a classification of special characteristics of behavior style to determine communication styles, which are divided into four categories, namely as The Relator, The Socializer, The Thinker, and The Director (Jensen, 2001). Each category of characteristics is presented in detail in the following image.

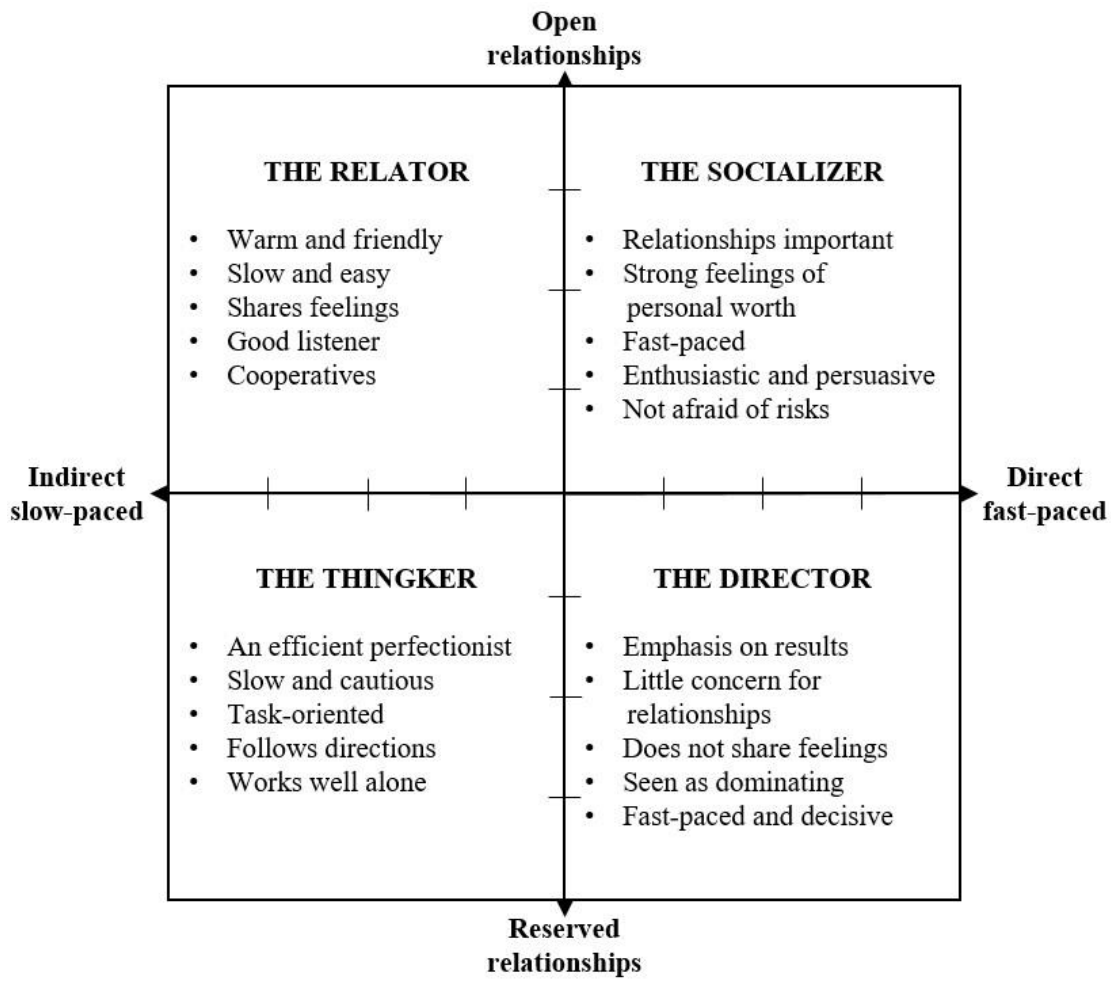

Figure 1. Behavioral style and communication type.

(Source: Jensen, 2001)

In the image, it can be seen that basically, The Relator quadrant is dominated by a slower pace (indirect) and a relationships-oriented approach (open); The Socializer quadrant indicates both a desire to build relationships (open) and a fast-paced, aggressive approach (direct); The Thinker is the quadrant dominated by a slower pace (indirect) and a closed personal style (reserved); The Director quadrant is dominated by a fast pace (direct) and by an 
almost nonexistent concern for relationships (reserved) is for directors, who are best known for reviews their often aggressive, competitive natures (Jensen, 2001).

The study of artists' communication style is also assisted with the organizational communication concept because community of TSC artists has been formed as a large organization in the Sundanese community. Organizational communication can be defined as the process by which individuals stimulate meaning in the minds of other individuals by means of verbal or nonverbal messages in the context of a formal organization (Virginia, McCroskey, \& McCroskey, 2005). Therefore, communication style of TSC artists is examined by those two concepts.

This article examines the effect of TSC artists' communication style towards the existence of TSC art in Indonesia. Therefore, the study only focuses on observations and interviews with the TSC artists, such as the teachers (masters) and learners, observers, and appreciators who always follow performances of TSC. This study is significant as to see the link between the communication styles of Sundanese artists on the existence of TSC art, so that the art has managed to survive across ages, and even grow in line with time. TSC in Indonesia is one of the traditional art genres that survive from extinction, as hundreds of other traditional art in West Java, Indonesia has already extinct. As reported in various sources, that in the West Java Province, Indonesia, as many as 500 types of art are extinct, as many as 40 types are in a state of early dying, 25 types are in a state of final dying, and 15 types still exist (Guci, 2015; Hasan, 2016; Heriyanto, 2015; G. Kurnia, 2013, 2014; Sobari, 2012). From the data, TSC is one of the 15 types of art that still exist.

\section{METHOD}

The research method that is considered appropriate for this study is the qualitative method that has been explained by Miles and Huberman (1994) and Malik and Hamied (2014) with interdisciplinary approach. This approach was adapted from Rohidi (2011) because the focus of the study requires different approaches from different disciplines. Therefore, the arranged concept and/or theories from other disciplines, which are built in one thinking system that results in form of one explaining theory or guiding measurement or the methodological foundation in conducting the research, are fully transformed and translated as interdisciplinary studies of body of language (Rohidi, 2011, p. 67). In this study, the problem of communication among artists is examined using approaches from the fields of sociology, while the behavior of the artists is examined using approaches from the fields of psychology and cultural anthropology.

Subjects in this study were the observers, practitioners of TSC who do routine rehearsals and performances, and loyal appreciators who appreciate various TSC performances. The selected resources were the teachers (masters) of TSC, senior figures, and the learners of TSC. The study was conducted in two sites, namely in sanggar seni (art studio) Pakuwon in Sumedang regency and in sanggar seni Elis Rosliani in Bandung regency, West Java, Indonesia. Both regencies have a vital role in preserving TSC today.

The data were collected in three ways, namely: 1) observations to rehearsal and performance sites of TSC, including observations to radios broadcasting $T S C$; 2) interviews to explore a variety of important information related to the topic of this study; and 3) documentation study to find relevant secondary data or to support collected data. These procedures were done in order to reduce the risk of limited conclusions on the specific methods and data sources, and to improve the validity of the conclusions thus able to explore a wider area (Alwasilah, 2006, p. 150). 
Data analysis was performed using an interactive model, because basically, activities in qualitative data analysis are performed interactively and continued over time until they are completed (Miles \& Huberman, 1994; Rohidi, 2007). The data collected were then analyzed and linked to relevant theories to then be interpreted and understood, so as to produce a comprehensive conclusion.

\section{RESULTS}

\section{Communication between Practitioners and Appreciators}

At the beginning, the art of TSC was only performed for and enjoyed by the royalties. Now it has changed along with changes in the social order in the Sundanese people's life and TSC has spread to the wider community. Thus its practitioners are not only from the royalties, but also have been widely played by common people. Nowadays, the artists also come from office workers (civil servants), academics, even beginners in primary school to practitioners who have S-2 (master) and S-3 (doctoral) titles. In other words, the practitioners of TSC not only consist of pure artists whose main job are as artists, but also from other circles, that are people who are more indicative of self-actualization, as can be seen in the theory of hierarchy of needs as has been explained by Andjarwati (2015).

With the diversity of professions and social status, communication between them stays well-connected, particularly in TSC performance events. Based on observations and interviews, the communication can be seen in the TSC performances in both formal and informal events. The researchers discover the communication between practitioners and appreciators of $T S C$ through the following activities.

First, the event of TSC broadcast on television. TSC is aired by some local television channels, one of which is Televisi Republik Indonesia (TVRI) Bandung. On TVRI Bandung, TSC now airs once in a month or even in two months. Through this TSC broadcast on TVRI Bandung, it can be seen that there are quite a number of loyal appreciators from various regions, particularly in the province of West Java, who always appreciate various groups of TSC performing in turns on every broadcast. Information on the appreciators was identified through communication between artists or lovers of TSC itself. This includes information from the coordinator of the broadcast, Tatang Suganda, who states that he always communicates with the artists of TSC after the routine broadcast on television (Interview, February 26, 2016). Similar information was expressed by the presenters of the TSC broadcast in TVRI Bandung named Teti Affienti (Interview, February 26, 2016).

Second, TSC broadcast on the radio. Currently, one of the radios that still broadcast TSC once a week is eRKS FM 101.6 MHz, which is located at Prabu Geusan Ulun Street No. 125, Sumedang, West Java. In this radio, TSC is broadcasted every Saturday for three hours starting at 06:00 until 09:00 at night. The performer in the event is Gentra Pakuwon circle of art in Sumedang regency. Based on observations and also information from the head of the Gentra Pakuwon, Noeroni Hidayat Soeriadikoesoemah, there are a lot of listeners of TSC from various regions in West Java who usually call to the radio (Interview, February 13, 2016).

\section{Communication between Senior Artists}

In this context, researcher has identified three attitudes of senior practitioners. The first attitude is willing to work together to train the juniors at the same time and place. Typically, these seniors are already accustomed to work together as a group in TSC events or performances. The second attitude is not willing to work together to train the junior at the same time and place. This attitude does not mean that they are individualistic; rather they are 
more likely to be the more respectful for other TSC practitioners who have different styles in giving training or different materials in training such as in the case of variations or ornamentation in the songs. Thus, this attitude seems to have a purpose of avoiding conflict among fellow practitioners of TSC. The third attitude is openness in terms of materials of the music or vocals in TSC. This attitude is shown in at least two symptoms, first, senior practitioners who always ask other senior practitioners when they have forgotten a particular material or song either in terms of melody or ornamentation, thus communication is established between the two parties in form of both direct communication (face to face) and also via mobile phone; second, senior practitioners who bring their students to be trained by other senior practitioners as an attempt to add the vocabulary of song ornamentation or play variations in the musical accompaniment.

The topics of conversation between senior practitioners senior are always varied. When senior practitioners meet, the usual discussions include: their respective activities as information especially for senior practitioners who rarely meet; other TSC practitioners concerning how they are doing and their artistic activities or routines; the development of their students; and problems that commonly arise in the TSC community such as about vocal contests.

\section{Communication between Junior Artists}

The style of communication and interaction between junior practitioners of TSC is quite diverse. Diversity occurs because of kinship background factor. Hence, in what context did the kinship exist? There is a kinship that exists because the persons were schoolmates, and there is a kinship that exists because the persons happened to meet at rehearsals. Because of the kinship differences, the communication style that occurred also tend to differ. For example, the communication style between junior practitioners at TSC rehearsal location in Sanggar Seni Pakuwon Sumedang tend to be formal and serious, because of the heterogeneity of TSC learners, both in terms of age or school level. The students are from primary school, secondary school, high school, college, and college graduates. The atmosphere melted only at certain times because their friendships were not so close.

In contrast to the communication style that occurred at the TSC rehearsal place in Sanggar Elis Rosliani in Bandung. Here, the communication style between junior practitioners tends to be free and relaxed because they are generally schoolmates in a vocational school of art namely SMK 10 Bandung. Hence, during rehearsal process, there is a friendly atmosphere that shows social closeness. They seem free to joke around and laugh, even laugh at each other freely if someone made a mistake when playing a song. This means that the homogeneous kinship that occurs because of being schoolmates showed more closeness and freedom than the kinship that exists only because of meeting in rehearsal places.

\section{Communication between Junior and Senior Artists}

The style of communication in this context is also quite diverse. Each studio or places of rehearsals has coaches or teachers with different characteristics. There are coaches who tend to be serious and hard, while there are also coaches who are always relaxed and like joking. For example, in Sanggar Pakuwon in Sumedang had invited coaches for songs several times. The former guest coaches tended to be serious and hard, thus communication with the learners also tended to be rigid. As a result, the learners were not free to express themselves both during rehearsals and in communications during rehearsals, because there were tensions that had an impact on their psychological condition. The condition were tried to be changed by a 
new coach (2016), namely Ujang Supriatna. The new coach always motivate and joke with the learners to break the ice in rehearsals, and to make the learners felt free, without tension, express themselves freely.

The style of communication between senior and junior practitioners that tend to be relaxed and free can be found in Bandung, among others places, with Elis Rosliani as the song coach. In this place, the communication between the coach and learners is quite dynamic, free and relaxed. In other words, the atmosphere is fluid, not rigid, so the language for communication used by learners is not overly polite. This is tolerated by the coach, so it seems there is not any offense, especially on the part of the coach who even communicate actively with the learners. Jokes are thrown out from both sides, which of course become the warmer for the rehearsal. This condition is created because basically the social relations among them are built from the relationship of teacher and student in an art school namely SMK 10 Bandung. This means that the close social relationships has already existed long enough in the school environment.

The closeness between senior and junior TSC artists could be also seen when a meeting was held in preparation for the the $21^{\text {st }}$ Tembang Sunda Cianjuran Damas (a Sundanese student organization, Daya Mahasiswa Sunda) contest on September 28, 2016 at the Cultural Center Foundation building (YPK/Yasasan Pusat Kebudayaan) Bandung. The senior figures and young artists of TSC gathered, interacted, and even discussed various issues related to the preparation of the contest. In the conversations, greetings between individuals were given, especially the artists who rarely met, before and after discussions. Here, senior figures showed closeness to all attending artists. In other words, senior artists did not impose limits or barriers in communication, instead they communicated actively with young artists, including providing motivations for young artists, such as encouraging them to be more active in TSC as an attempt of regeneration.

Kinship that exists between TSC artists is caused because the roles of Damas as the organizer of the TSC contest. The organization appreciate the existence of TSC artists both the old and the new generations. This is evident in the invitations sent by Damas to various groups of TSC artists, including the researcher. The invitation was sent by the contest committee chairman himself via SMS, as accepted by the researcher (Personal Communication, September 25, 2016 at 12:29 p.m.) with contents of the invitation (in polite Sundanese) as follows:

"Salam, panitia PTS 2016 damas, nu baris dilaksanakeun ping 10 dk 13 okt di ged budaya sabilulungan, ngulem akang/ceuceu kanggo sumping dina gempungan, dinten rebo, 28 sept tbh 15.00 dk rengse di ypk jl. Naripan, hatur nuhun".

Translation: "Regards, the committee of PTS 2016 Damas, which will be held on 10 until 13 October at Sabilulungan cultural building, invites akang/ceuceu [call in Sundanese for older brother and sister] to come for a meeting on Wednesday, September 28 at 15.00 until finished at YPK, Naripan Street. Thank You.

The essence of the above SMS is that the contest organizer invited TSC artists to attend a meeting or aggregate at YPK building on September 28, 2016 at 15:00 until finished. It asserted that although there was already an organizer, Damas still invited various parties to meet. Thus, it becomes one of the main evidence of kinship and communication that exists in the TSC community in Indonesia. 


\section{Communication between Observers of Tembang Sunda Cianjuran}

Besides having practitioners that supports the life of the art, TSC art also has observers who witness every development of the art, thus being complementary aspect of TSC art development. Based on the way of expressing their observations, at least two groups of observers are identified. The first group is observers who are also academics. This group generally has the ability to write, thus communication with others could be done in a form of writing in magazines, newspapers, or textbooks. The second group is the non-academic observers. The people in this group generally actively highlight the development of TSC not through writing, so they communicate through discussions or orally. In addition to the two groups of observers, there are also observers who are both artists and practitioners of TSC, and some other observers who are not TSC practitioners, so communication can be done either written or orally.

The TSC observers in general can be seen when there was a socio-cultural phenomenon or occurrence in the TSC community, particularly related to the development of musical or vocal aspects of TSC. As happened in 2009, when Damas' $19^{\text {th }}$ Pasanggiri (contest) of TSC (PTSC) was held-where the committee of PTSC had a new concept to use new songs in the contest, so it commissioned several TSC artists to create new songs. From the creation of the artists, new songs were composed, but some selected songs by TSC experts drew controversy from various circles of TSC because it was not in accordance with the rules or characteristics of $T S C$, namely a song created by the Sundanese artist, Ubun Kubarsah.

Ubun Kubarsah has a different concept related to the new songs, he analyzes that the melody of TSC is simple, while the ornamentations are complex. Therefore, he made a new song (Sekar Anyar) with the innovation of making the melody more complex while the ornamentation is simplified. This innovation was considered odd by the general TSC community (Herdini, Personal Communication, May 20, 2016). This significant difference resulted in PTSC in 2009 to be divided into two categories, namely Tembang Sunda Cianjuran and Sekar Anyar. This became a hot issue at the time, so after the contest finished, various views surfaced, hence observers expressed their opinion by writing in the mass media, including the statement of TSC artists. Herdini (2010) states that the Sekar Anyar was worthy to be included into the genre of TSC based on the analysis of accompaniment and lyrics. Similar opinion was proposed by Hendrayana (2010) who states that the essence of TSC were also found in Sekar Anyar. Meanwhile, other TSC community members denied the existence of Sekar Anyar in the genre of TSC.

The above written views give an illustration that the TSC art is classified as a traditional art in West Java, which is loved, cared for, and observed by various parties, especially by the TSC community itself. This also illustrates that the TSC community has observers who watches every movement of TSC in its journey and communicate based on their expertise.

\section{DISCUSSION}

Based on the findings, the followings are identified. First, the communication between the TSC artists occurs in several directions, namely communication between practitioners and appreciators, between observers, between senior practitioners, between junior practitioners, and communication between junior and senior practitioners. This means that the occurred communication are the diagonal, horizontal, downward and upward communication (Purwanto, 2006). Diagonal communication occurs between practitioners and appreciators of TSC, or between practitioners and observers of TSC. Horizontal communication occurs between peer artists or between junior artists, and communication between senior artists. Downward communication occurs from senior to junior artists, and upward communication 
occurs from junior to senior artists, such as the communication of pupils to the teachers of TSC. According to Keyton (2011, p. 12) communication with this varied directions result in positive impact on the preservation of $T S C$, since it is very clear that an organization cannot survive without communication.

Second, the method of communication between artists in the TSC community occurs in several methods. In general, communication is done verbally and this is in accordance with the eastern culture, Indonesia in particular, which has oral tradition, thus information about TSC was communicated orally. Basically, tradition can be seen from two different perspectives, literacy (writing systems) and oral traditions (Duija, 2005). As disclosed in one of the resources, the oral tradition in Java is a way to pass down cultural knowledge from the older generation to the younger generation (Soehardi, 2002, p. 1). As for communication through writing, it is only done by academics, including the TSC observers.

Third, the communication styles formed in the TSC community are closely related to factors of behavior, motivation, awareness, and a sense of belonging to the art of TSC. The behaviors exhibited by the song teachers or accompaniment instrument teachers in TSC show more positive attitude to accept students who want to learn the song or accompaniment music without any special demands in terms of riches or honorarium. There is no indication of hierarchy in the process of communication, or there are more indications of equality, especially in terms of social status. Therefore, it brings more positive impact on the existence of TSC. This positive attitude is very important in maintaining TSC, and even very valuable for the students. Goldberg and Larson (1985) state that equality means that every individual is able to accept the other, or giving a positive appreciation toward the others without any requisite. This means that positive action is important because the communication will work well when the people inside have a positive behavior toward themselves or others, so they can support themselves in order to respect the importance and existence of other people (Muslimin, 2017).

The communication style in the learning process - with teachers who are more relaxed and full of familiar atmosphere - is proved to be more communicative because it gives freedom to the learners to express themselves more freely and to demonstrate their potential to the fullest. In other words, a climate of friendly communication encourages members of the organization to communicate in an open and relaxed way with other members. Conversely, negative climate results in discouragement of members to communicate openly and friendly (Evelina \& Angeline, 2013; Muhammad, 2005).

The findings of this study are presented in summarized in the following table.

Table 1. Communication styles of TSC artists.

\begin{tabular}{|c|c|c|c|}
\hline Community & $\begin{array}{l}\text { Direction of } \\
\text { Communication }\end{array}$ & $\begin{array}{l}\text { Method of } \\
\text { Communication }\end{array}$ & $\begin{array}{l}\text { Style of } \\
\text { Communication }\end{array}$ \\
\hline Appreciators & Diagonal Communication & Verbal & $\begin{array}{l}\text { Relator \& } \\
\text { Socializer }\end{array}$ \\
\hline Observers & Diagonal Communication & Verbal and Written & Thinker \& Relator \\
\hline Junior Artists & $\begin{array}{l}\text { Horizontal Communication } \\
\& \text { Upward Communication }\end{array}$ & Verbal & $\begin{array}{l}\text { Relator \& } \\
\text { Socializer }\end{array}$ \\
\hline Senior Artists & $\begin{array}{l}\text { Horizontal Communication } \\
\text { \& Downward } \\
\text { Communication }\end{array}$ & Verbal & $\begin{array}{l}\text { Relator \& } \\
\text { Socializer }\end{array}$ \\
\hline
\end{tabular}




\section{CONCLUSION}

Based on the findings and discussion, it can be concluded that the communication style woven by artists in the TSC community in Indonesia is more dominant on the type of relator and socializer. As a result, TSC art still have loyal enthusiasts because the communication is done in a warm, familiar or friendly atmosphere. In this way, as a result, the existence of TSC is maintained from generation to generation. The learners also have teachers or masters TSC who still hold the values of local wisdom in how to pass their knowledge so that good communication occurs between both parties. Appreciators and observers remain sensitive and reactive to all of the phenomena that occur in the development of music and vocals in TSC, thus becoming social control in the face of changes in TSC. Practitioners of TSC in general are people who also already have steady jobs, so that the artistic activity in TSC has become a necessity which is mentioned in the Maslow's theory of needs as self-actualization (Poston, 2009).

\section{References}

Alwasilah, A. C. (2006). Pokoknya kualitatif: Dasar-dasar merancang dan melakukan penelitian kualitatif. Jakarta: Pustaka Jaya.

Andjarwati, T. (2015). Motivasi dari sudut pandang teori hirarki kebutuhan Maslow, teori dua faktor Herzberg, teori x y Mc Gregor, dan teori motivasi prestasi Mc Clelland. Jurnal Ilmu Ekonomi \& Manajemen, 1(1), 45-54.

Bhatia, V. K. (1995). Genre-mixing in professional communication. The case of private intentions v. socially recognized purposes. In P. Bruthiaux, T. Boswood, \& B. Du-Babcock (Eds.), Explorations in English for professional communication (pp. 1-19): City University.

Bhatia, V. K. (2010). Interdiscursivity in professional communication. Discourse \& communication, 4(1), 32-50.

Blyler, N. R., \& Thralls, C. (1993). Professional communication: The social perspective: Sage Newbury Park, CA.

Cathcart, J., \& Allesandra, T. (1984). Relationship strategies. Chicago: Nightingale Conant Corporation.

Craig, R. T. (2007). Communication theory as a field. In R. T. Craig \& H. L. Muller (Eds.), Theorizing communication: Reading across traditions (pp. 63-98). Los Angeles: Sage Publications.

Duija, I. N. (2005). Tradisi lisan, naskah, dan sejarah; Sebuah catatan politik kebudayaan. Wacana, Journal of the Humanities of Indonesia, 7(2).

Evelina, L., \& Angeline, M. (2013). Komunikasi vertikal dan horizontal dalam membentuk gaya kepemimpinan berbasis kearifan lokal (studi pada binus university). Retrieved from http://marcomm.binus.ac.id/academic-journals/komunikasi-vertikal-dan-horizontal-dalam-membentukgaya-kepemimpinan-berbasis-kearifan-lokal-studi-pada-binus-university/

Fajar, A. (2011). Konvergensi dalam social (new) media (kajian tradisi kritis sosial budaya terhadap teoritisasi komunikasi antar pribadi, massa dan digital). Semantik, l(1).

Fisher, B. A. (1978). Perspectives on human communication: MacMillan Publishing Company.

Fiske, J. (2003). Introduction to communication studies (2 ed.). London: Routledge.

Franksiska, R. (2006). Communication style. Bina Ekonomi, 10(1), 1-12.

Gladyshev, V., Kouznetsova, A., \& Penner, R. (2016). Communication as a factor of achieving a holistic being in the age of networked media. Rupkatha Journal on Interdisciplinary Studies in Humanities, 8(4), 96105. doi:https://dx.doi.org/10.21659/rupkatha.v8n4.11

Goldberg, A. A., \& Larson, C. E. (1985). Komunikasi kelompok: proses-proses diskusi dan penerapannya. Jakarta: Universitas Indonesia.

Griffin, E. (1991). Communication theory: A first look. New York, McGrawHill.

Guci, T. M. (2015). Ini alasan kesenian dan kebudayaan Sunda buhun nyaris punah, kamu harus tahu! Tribun Jabar. Retrieved from Tribun Jabar website: http://jabar.tribunnews.com/2015/12/07/ini-alasan-keseniandan-kebudayaan-sunda-buhun-nyaris-punah-kamu-harus-tahu

Hardjana, A. (2004). Teori komunikasi: Kisah pengalaman Amerika. Jurnal Ilmu Komunikasi, 1(2), 95-112.

Hargie, O. (1997). The handbook of communication skills: Psychology Press.

Hasan, H. R. (2016). 300 seni tradisional jawa barat terancam punah Tempo. Retrieved from Tempo.co website: https://m.tempo.co/read/news/2016/08/25/090798991/300-seni-tradisional-jawa-barat-terancam-punah 
Heidegger, M. (1971). Thing: Poetry, language, thought. New York: HarperCollins Publishers Inc.

Hendrayana, D. (2010, August 8). Wanda baru cianjuran. Pikiran Rakyat, p. 21.

Herdini, H. (2010, August 8). Sekar anyar dalam cianjuran. Pikiran Rakyat, p. 21.

Heriyanto, R. (2015). Puluhan seni tradisional terancam punah. Pikiran Rakyat. Retrieved from Pikiran Rakyat website: $\quad$ http://www.pikiran-rakyat.com/seni-budaya/2015/11/22/350806/puluhan-seni-tradisionalterancam-punah

Huntington, S. P. (1992). Book review the third wave democratization in the late twentieth century. Retrieved from http://www.scottlondon.com/reviews/huntington.html

Jensen, D. G. (2001). Behavioral Style: Understanding Communication Styles Can Advance Your Relationships and Your Career Prospects, Part $2 . \quad$ Retrieved from http://www.sciencemag.org/careers/2001/04/behavioral-style-understanding-communication-styles-canadvance-your-relationships-and

Jensen, D. G. (2004). Chapter 5: Communication Skills for Scientist Leaders (Part Two). Retrieved from http://www.todroberts.com/USF/CommunicationSkillsForLeaders.pdf

Jung, C. (1974). Psychological types. San Diego, California: Harcourt, Brace and Company.

Keyton, J. (2011). Communication and organizational culture: A key to understanding work experiences. Thousand Oaks: Sage Publications.

Kurnia, G. (2013). Mangle dan wahyu wibisana raih "anugerah rumawat pajajaran". Pikiran Rakyat Online. Retrieved from http://www.pikiran-rakyat.com/seni-budaya/2013/09/05/249405/mangle-dan-wahyuwibisana-raih-anugerah-rumawat-pajajaran

Kurnia, G. (2014). Rektor unpad minta caleg DPRD Jabar terpilih jaga kelestarian seni Sunda. Retrieved from http://www.unpad.ac.id/2014/06/rektor-unpad-minta-caleg-dprd-jabar-terpilih-jaga-kelestarian-senisunda/

Kurnia, N. (2005). Perkembangan teknologi komunikasi dan media baru: Implikasi terhadap teori komunikasi. Mediator, 6(2), 291-296.

Littlejohn, S. W. (1999). Theories of human communication (8th ed.). Belmont: Wadsworth Publishing Company.

Mahmudah, D. (2011). Evolusi teori ketergantungan sistem media menjadi teori infrastruktur komunikasi. Jurnal Studi Komunikasi dan Media, 15(2).

Malik, R. S., \& Hamied, F. A. (2014). Research methods: A guide for first time researchers. Bandung: UPI Press.

Mayhew, L. H. (1997). The new public: Professional communication and the means of social influence: Cambridge University Press.

Miles, M. B., \& Huberman, A. M. (1994). Qualitative data analysis: An expanded sourcebook: sage.

Miller, K. (2004). Communication theories: Perspectives, processes, and contexts: McGraw-Hill Humanities/Social Sciences/Languages.

Muhammad, A. (2005). Komunikasi organisasi. Jakarta: Bumi Aksara.

Mukhlishin, M. I., Maryaeni, M., \& Pratiwi, Y. (2016). Bentuk gaya bahasa komunikasi facebook komunitas seniman laki-laki. Jurnal Pendidikan: Teori, Penelitian, dan Pengembangan, 1(6).

Muljono, W., Setiyawati, S., \& Haryanto, B. (2017). Technological determinism in patterns of communication and social behavior change in Indonesian society. Asian Social Science, 13(2), 21-32. doi:http://dx.doi.org/10.5539/ass.v13n2p21

Muslimin, M. (2017). A traditional communication of bugis (note 1) in the south sulawesi of indonesia through the art performance of kecapi. Asian Social Science, 13(3), 21-30.

Pan, Y., Scollon, S. B., \& Scollon, R. (2002). Professional communication in international settings: OECD Publishing.

Poston, B. (2009). Maslow's Hierarchy of Needs. surgical technologist, 41(8).

Purwandoko, H., \& Prasetyo. (1993). Keefektifan komunikasi hukum (suatu kajian teoritis). YUSTISIA, 23, 2937.

Purwanto, D. (2006). Komunikasi bisnis edisi ketiga. Jakarta: PT Gelora Aksara Pratama.

Rahardjo, T. (2011). Konstruksi teori (komunikasi) dalam logika hypothetico-deductive. Jurnal Ilmu Komunikasi, 8(2).

Rejeki, S., \& Ninik, M. C. (2010). Perspektif antropologi dan teori komunikasi: Penelusuran teori-teori komunikasi dari disiplin antropologi. Jurnal Ilmu Komunikasi, 7(1), 41-60.

Rohidi, T. R. (2007). Analisis Data Kualitatif ((Trans), Trans.). Jakarta: Universitas Indonesia.

Rohidi, T. R. (2011). Metodologi Penelitian Seni. Semarang: Cipta Prima Nusantara.

Santosa. (2012). Komunikasi seni aplikasi dalam pertunjukan gamelan. Surakarta: ISI Press Surakarta. 
Sobari, N. (2012). 40 jenis kesenian tradisional di jabar nyaris punah. Pikiran Rakyat. Retrieved from Pikiran Rakyat website: http://www.pikiran-rakyat.com/seni-budaya/2012/02/23/178057/40-jenis-keseniantradisional-di-jabar-nyaris-punah

Soehardi. (2002). Nilai-Nilai Tradisi Lisan Dalam Budaya Jawa. Jurnal Humaniora, 14(3), 1-13.

Stacks, D. W., Hill, S. R., \& Hickson, M. (1991). An introduction to communication theory: Holt Rinehart \& Winston.

Sunarto, D. R. (2013). Berteori dalam penelitian komunikasi. INTERAKSI, 2(1), 50-61.

Surahman, S. (2005). Teori komunikasi dalam perspektif mazhab frankfurt. Mediator, 6(1).

Tatu, O., \& Arhire, M. (2012). Translation as a form of intercultural workplace communication. In S. Măda \& R. Săftoiu (Eds.), Professional communication across languages and cultures (pp. 239-264). Transilvania: John Benjamins Publishing Company.

Toffler, A., \& Alvin, T. (1981). The third wave. New York: Bantam Books New York.

Virginia, P. R., McCroskey, J. C., \& McCroskey, L. L. (2005). Organizational communication for survival making work. United States of America: Pearsom Education.

Visockis, M. (2015). The modern man: The future according to toffler. Retrieved from http://www.hourofthetime.com/wordpresstest/the-modern-man-the-future-according-to-toffler-vns-andcajiis-exclusive/

\section{Informants:}

Affienti, Teti (1965). Tembang Sunda Cianjuran Singer. Interview on Baleendah, Bandung.

Herdini, Heri (1966). Kacapi Indung Player; Lecturer in ISBI Bandung. Communication on Perum Bumi Langgeng Bandung, West Java.

Soeriadikoesoemah, Noerony Hidayat (1937). Sanggar Seni Pakuwon Owner. Interview on Jalan Raden Sujud 9 Sumedang, West Java.

Suganda, Tatang (1955). Tembang Sunda Cianjuran Singer. Interview on Baleendah, Bandung, West Java. 